\section{A NEW LOCALITY FOR MIOCENE MAMMALS}

Some time ago Mr. William Stein, one of my students, brought me a fragment of the lower jaw of some equine, containing two teeth, excellently preserved. The specimen was found at his father's ranch at Troublesome, in Middle Park Colorado, in the course of making a well. It was about thirty feet from the surface, in red soil. As no Miocene beds have ever been reported from this region, the discovery is a remarkable one. Photographs of the specimen (three aspects) were made and sent to Dr. J. W. Gidley, of the National Museum. He very kindly replied that it was difficult to determine the species, but the characters shown seemed to place it rather definitely in the genus Parahippus. The horizon was Middle or Upper Miocene. Dr. W. D. Matthew also kindly examined the photographs, and thought the animal was correctly referred to Parahippus, and of Miocene age.

Mr. S. A. Rohwer made a trip to Troublesome, in order to search for further materials, but although he carefully examined all the surrounding region, he could not find any fossils. It seems probable that the deposit is quite local, and it may be that only extensive excavations at the Stein ranch will uncover the fossiliferous beds.

\section{UNIVERSITY OF CoLORADo}

\section{T. D. A. Cockereli}

\section{EDUCATION AND THE TRADES}

I READ with much interest "The High School Course," by President David Starr Jordan in The Popular Science Monthly for July. While the tenor and purpose of the article as a whole are commendable, as progressive and liberal, one sentence contained therein shows that President Jordan is not unlike the orthodox ministers and church members, who pride themselves upon their broadmindedness in having renounced the fire and brimstone hell, although they still hold fast to the devil-or who would look after the bad people, pray? ing:

The sentence to which I refer is the follow-

But the purpose of this training must be intel- lectual, not to teach a trade, and only secondarily to fit for engineering courses of the universities.

Not to teach a trade! Why not lift the trades out of the gutter? and acknowledge them to be suitable, yea, fertile fields for intellectual activity?

President Jordan says :

The development of manual training of some sort for all boys and girls will represent the greatest immediate forward step in secondary education.

Why? Simply because it is an approach toward the proper recognition and appreciation of that which is practical and useful.

In noting the great hue and cry which has gone over the country against child labor, I have often thought that these children who labor are not much more sinned against than the school children who are shut up in school rooms day after day and forced to study things which seem wholly foreign to their lives. They are obliged to sacrifice their most receptive years to the old traditional idea of education which consisted in the acquisition of so-called intellectual knowledge; of knowledge which was out of the reach of the working people, held aloft and kept free from contamination with the vulgar trades; knowledge which could never be degraded by use, in earning a living. Is it not high time that we break away from these shackles of tradition, and no longer wrong the trades by ostracizing them and considering the mastery of a trade something separate and apart from an intellectual pursuit?

A trade is defined as:

An occupation, especially mechanical employment, as distinguished from the "liberal arts"-the learned professions, and agriculture. As, we speak of the trade of a smith, of a carpenter, or a mason, but, not now of the trade of a farmer, or a lawyer, or a physician.

This now, in the definition, shows that the farmer, lawyer and physician used to belong among the "tradespeople."

The intellectual boundaries will not suffer if the trades enter in. The old " no-trespassing" signs must come down, and the trade-idea must be elevated and placed upon a par with the so-called liberal arts. 